\title{
THE EFFECTIVENESS OF AUTHENTIC MATERIALS FOR READING COMPREHENSION ON STUDENTS' MOTIVATION
}

\author{
Desi Nurazimi $^{1}$, Hendi Hidayat ${ }^{2}$ \\ ${ }^{1,2}$ IAIN Syekh Nurjati Cirebon \\ Email: hendilegowo86@gmail.com
}

\begin{abstract}
The research was about to examine the effectiveness of authentic materials implementation on the students' motivation at the tenth grade of SMA Negeri 1 Sumber. The research method is quantitative research with quasi experimental research design. The population of the research is all of MIPA students at the tenth grade and the sample are students of X MIPA 7 and X MIPA 8 that consist of 72 students. The techniques of collecting data are questionnaire and observation. Therefore, the research findings showed that students' response in experimental class has a very good result after the treatment with the mean 86.42 from 69.18 and the Paired Sample T-test score is 0.00 means that there is a significant result after the treatment. However, students' response in control class is not really showed the good result because it decreased from 69.76 to 68.87 with the Paired Sample T-test 0.429 means that there is no significant result after the treatment. In addition, the hypothesis test using Analysis of Covariances (ANCOVA) was pointed out that the significant was 0.00 means lower than 0.05 . It is indicated that $\mathrm{Ha}$ is accepted, namely there is a significant result of students' motivation from the use of authentic materials for reading comprehension. This research gives suggestion to the teachers as the consideration of the materials they use in teaching.
\end{abstract}

Keywords: Authentic Materials, Reading Comprehension, Students' Motivation

\section{INTRODUCTION}

Reading is one of important skills in learning language. Moreover, it is a process shaped partly by the text, partly by the reader's background, and partly by the situation of the reading occurs in (Hunt, 2004). Through this activity, the students can improve their language skills and experience. This statement also supported by Brown (1994), reading is treated as one of two or more interrelated skills. A course that deals with reading skills will also deal with related listening, speaking, and written skills. It can be said that by reading the text, student can integrate the other skill. They also can get the information and a new idea of what they have read. Besides, they will be able to know what they do not know before.

Therefore, in order to get the truly information from the reading text, student have to comprehend the text to fully understanding about the text means. Richards and Renandya (2002) 
states that "reading for comprehension is the primary purpose for reading (though this is sometimes overlooked when students are asked to read overly difficult texts); raising students' awareness of main ideas in a text and exploring the organisation of a text are essential for good comprehension.

Reading is one of the English learning instruction that has a certain purpose. Permendiknas No. 22 year 2006 stated that English teaching has the goals to support the students in achieving their competencies to: (1) increase their communicative competences, oral or written, to achieve the functional literacy level; (2) have awareness about the importance of English to increase the Indonesian capability in competing with other nations in the world; and (3) increase students' understanding about interrelationship between language and culture.

In order to achieve the goals of learning instruction, we need some aspect to support it. Some aspects included approach, material, method and assessment are the basis important in learning instruction. One of the most important in learning is material. Nowadays, learning materials in our curriculum applied the scientific approach that has some differences from the previous approach in teaching and learning process. Scientific approach is the approach adopted from 2013 curriculum. The 2013 curriculum is a curriculum that can educate future competency, communication skills, ability to think clearly and critically, ability to consider the moral aspects of a problem (Kemdikbud, 2013). Based on that statement, 2013 curriculum guide students to have both soft skill and hard skill to face the future. The process of learning and teaching emphasizes student - cantered learning in order to make students more active than teacher in the class. The goals of this curriculum are improving students' responsibility in case of good attitude, interpersonal relation and to think critically.

Scientific approach as its implementation has some steps to do; they are observing, questioning, experimenting, associating and communicating. The developing of approach make the material of teaching developed too. The material of teaching is not enough if it is just from the course book of the students to interact them in the learning process. Course book is one of the alternative teaching materials that usually include worksheet and record of the material. The other alternative teaching materials recently used as the innovation in education is authentic materials. The authentic material is usually called by "a real life material". Mitchell (1995) describes authentic material as material that was originally produced for native speakers. According to this argument, authentic material can be identified as the sources of material that came from the reality or what really happen in real life. 
The authentic materials has some criterion like newspaper, magazine, a real life conversation, and so on. Reading skill is the most skill that usually required to use authentic material as the teaching material. By reading the authentic material, students can know what really happen in life and they can get the more knowledge from them. It is supported by Gilmore (2007) and Widdowson (2003) that developing learners' ability to cope with natural language calls for using authentic materials drawn from natural contexts. But, in reality, most of the students have the difficulties to understand about what they have read instead usually they just read a part or some sentences in one passage or information. They usually feel difficult to understand about the general and main idea, explicit and implicit information also the meaning of the words itself.

One of the causes of these problems are students' motivation. Motivation is very important in learning process. As Ames (1990) said that motivation to learn is characterized by long-term, quality involvement in learning and commitment to the process of learning. It takes a big role in improving students' skill because motivation can encourage students to be more active and enthusiasm to enjoy the learning so the material will be absorbed well. Students with the high motivation usually perform better than the low motivation students. There are some factors that possibly causes students' low motivation in the learning, such as teaching material that is not familiar with the environment, teaching material is monotonous, the class is dominated by the teacher and students do not have the more space to point their communicative competence.

Those identifications of causes also happen in SMA Negeri 1 Sumber as the researcher has observed. The observation showed that students' vocabulary are lack so they sometimes feel difficult to understand the meaning of what they have read. Students' motivation in reading are low so they often lazy to join the learning process so it makes the class is passive. Mostly, the activities of teaching reading are students just read the text from the course book then they fill the exercises provided. So, the students is not really active in learning English especially in reading. Moreover, the teacher only implement the material from the course book and they are still dominated in the classroom so the students cannot explore more by themselves.

However, the authentic material possibly can be used as the alternative teaching material that can motivate students more in reading activity. The authentic materials give more option to learn from another sources and it's good to improve students' motivation in learning teaching. Reading activity cannot separated with our daily life, by reading we can know anything what we have not known before. That is why reading skill is taught in the school. To improve the students' motivation toward reading skill, English teachers need to know the nature of reading, how to teach 
reading effectively, and what instructional materials is the most suitable for their students, in addition to pedagogical competencies. Therefore, this research focused on examining the effectiveness of authentic materials on students' motivation.

\section{METHOD}

\section{Methods}

The method that has been used in this research is quasi experimental research design. Quasi experimental research design used because of there is difficulties to get control group of the research (Sugiyono, 2015). Actually, the quasi experimental method considered as the appropriate research design method for this study. In the treatment group (experimental) implemented the learning process by using authentic materials, while the control group carried out the conventional learning process by using textbook. Thus, the research design will be used Non - equivalent Control Group Design where this is similar to the pretest-posttest control group design, but, in this design the experimental group or the control group is not randomly selected. In this design, both the experimental and control groups were compared, although the group was selected and placed without randomization. Two groups were given pretest, then given treatment, and lastly given posttest.

\section{Population of the Research}

Population of the research is related to subject or object which have the certain characteristics. Sugiyono (2015) said that population means the generalization area involves the object or the subjects that have certain qualities and characteristics regarding researchers cosideration to be studied and drawn the conclusion. The population in this study is all students of X MIPA grade at SMAN 1 Sumber of academic year 2017/2018. There are consist of 8 classes with approximately 36 students in each class.

Table 3.2

The Number of Class and Student of X MIPA

\begin{tabular}{cc}
\hline Class & The Number of Students \\
\hline X MIPA 1 & 36 \\
\hline X MIPA 2 & 40 \\
\hline X MIPA 3 & 36 \\
\hline X MIPA 4 & 33 \\
\hline X MIPA 5 & 36 \\
\hline X MIPA 6 & 35 \\
\hline
\end{tabular}




\begin{tabular}{cc}
\hline X MIPA 7 & 36 \\
\hline X MIPA 8 & 36 \\
\hline Amount & $\mathbf{2 8 8}$ \\
\hline
\end{tabular}

\section{Sample of the Research}

Sample of the research is the part of population. According to (Sugiyono 2015), research sample means the part of number and characteristics of population. Precisely, if the population is large, the researcher can be used the sample of the population. The sample in this research is students at grade X in second semester at SMAN 1 Sumber of academis year 2017/2018. It consists of 2 classes namely X MIPA 7 class that consists of 36 students as an experimental class and X MIPA 8 classthat consists of 36 students as a control class, so there are 72 students as the sample of this research. The reason of choosing those classes is because the researcher found the problemms related to this research in those classes.

\section{Technique of Data Collection}

Sugiyono (2013) states that data collection techniques is the most strategic step in the study, because the main purpose of research is to obtain data. Technique of data collection in this research is observation and questionnaires. The explanation are:

\section{Questionnaire}

Questionnaire used to find out students' motivation in the learning activities. In this case, questionnaires emerged as the technique of collecting data by submitting the list of questions or statements and then filled by respondents (Arikunto, 2005). In this study, questionnaire is done to find out students' motivation in using authentic materials in the learning process. Questionnaire used in this study using Likert scale. According Sugiyono (2016), Likert scale is used to measure attitudes, opinions, and perceptions of a person or group of people about social phenomena. Here Likert scale scores table:

Table 3.3

\section{Likert Scale}

\begin{tabular}{cc}
\hline Alternative Answers & Positive Statement Score \\
\hline Strongly Agree & 5 \\
\hline Agree & 4 \\
\hline Neutral & 3 \\
\hline Disagree & 2 \\
\hline Strongly Disagree & 1 \\
\hline
\end{tabular}

(Sugiono. 2016:135) 


\section{The Validity and Reliability of the Instrument}

Validity and reliability aims to determine the extent to which a questionnaire is made precisely and reliably for a study. This test needs SPSS program of Correlation of Product Moment.

\section{1) The Validity of the Instrument}

Validity is defined as the accuracy, correctness and legitimacy of the measurements during data collection (Phakiti, 2014). This test is done by comparing $r$ arithmetic with $r$ table. If $r$ count is greater than $r$ table then the item is valid and vice versa. $\mathrm{R}$ count is searched using SPSS program, while $\mathrm{r}$ table is searched by looking at table $\mathrm{r}$ with the minimum $\mathrm{r}$ requirement being 0.3 . The result of validity test instrument can be seen in the appendix.

\section{2) The Reliability of the Instrument}

According to Phakiti (2014), an instrument is reliable if it produce scores consistently. This test is done by comparing the minimum cronbach alpha number is 0.6. It means that if the value of cronbach alpha is greater than 0.6 then it is concluded that the questionnaire is reliable and vice versa.

\section{Table 3.4}

\section{The Category of Reliability Coefficient}

\begin{tabular}{cc}
\hline Reliability Coefficient & Category \\
\hline $0.800-1.000$ & Very High \\
\hline $0.600-0.799$ & High \\
\hline $0.400-0.599$ & Fair \\
\hline $0.200-0.399$ & Low \\
\hline $0.000-0.199$ & Very Low
\end{tabular}

Based on the computation using Cronbach's Alpha in SPSS 20 Software, all the test both in experimental and control class was categorized as high reliability. The table 9 below presents the result of reliability test of the instrument, while the complete calculation is in Appendix. 
Table 3.5

The Value of Reliability

\begin{tabular}{ccc}
\hline Variable & $\begin{array}{c}\text { Reliability } \\
\text { Coefficient }\end{array}$ & Category \\
\hline $\begin{array}{c}\text { Pre-test of } \\
\text { Experimental Class }\end{array}$ & 0.894 & Very High \\
\hline $\begin{array}{c}\text { Pre-test of Control } \\
\text { Class }\end{array}$ & 0.888 & Very High \\
\hline $\begin{array}{c}\text { Post-test of } \\
\text { Experimental Class }\end{array}$ & 0.860 & Very High \\
\hline $\begin{array}{c}\text { Post-test of Control } \\
\text { Class }\end{array}$ & 0.823 & Very High \\
\hline
\end{tabular}

\section{Technique of Data Analysis}

The most important stage in a research is the stage of data processing, because at this stage the results of the study formulated. After the data is collected as a whole, it will describe the research data with the following stages:

\section{Normality Test}

Normality test used to determine the normalized level of samples that have been studied. In this case, the researcher examine normality data by using kolmogorov-Smimov of SPSS 23 Software (the number of responden is $\geq 50$ ). Kolmogorov-Smimov test means normality test which used when the average and variant not yet known.

The hypotheses which examined are:

$\mathrm{H}_{0}$ : Data distributed normally

$\mathrm{H}_{\mathrm{a}}$ : Data undistributed normaly

Then, the consideration are:

If the score sig $<0,05$ so $\mathrm{H}_{\mathrm{a}}$ accepted

If the score $\operatorname{sig} \geq 0,05$ so $\mathrm{H}_{0}$ accepted

\section{Homogenity Test}

Homogeneity Test used in order to examine whether the sample is homogeneous or unhomogeneous. Actually, homogeneous test used levene of SPSS 21. Then, the result taken from the test output exactly Test of Homogenity of Variance. The hypothesis that examined are:

$\mathrm{H}_{0}$ The data from two population with same homogeneous variants 
$\mathrm{H}_{\mathrm{a}}$ : The data from two population with unhomogeneous variants

Then, the consideration are:

If the score sig $<0,05$ so $\mathrm{H}_{\mathrm{a}}$ accepted

If the score $\operatorname{sig} \geq 0,05$ so $\mathrm{H}_{0}$ accepted

\section{Analysis of Students' Data Instrument}

There are several steps of analysis for the instrument that has given to students. The steps are in the following explanation:

1) Questionnaires response analysis on authentic materials for reading comprehenson

The data analysis used to analyze students' response on authentic materials for reading comprehenson by calculating the average for each aspects then the formula is:

$$
\bar{x}=\frac{\sum x_{i}}{n}
$$

Information:

$\bar{x}=$ The average

$x=$ Responden score to- $\mathrm{i}$

$n=$ Number of responden

Then, changing the average score of students' response questionnaires into the folowing qualitative criteria:

2) Calculating the percentage of students' response

This step due to know the percentage of each item which chose by the students such as very agree, disagree, and so forth. According to Sudijono (2012: 43), stated that the formula of Calculating the percentage of students' response is:

$$
p=\frac{f}{N} \times 100 \%
$$

Information:

$$
\begin{aligned}
& P=\text { Last achieved result } \\
& f=\text { Proportion of students } \\
& N=\text { Number of respondent } \\
& 100 \% \quad=\text { Fixed numbers }
\end{aligned}
$$

To interpret the results, the authors are guided by the opinion of Roduwan (2012) as follows: 
Table 3.6

Interpretation of Percentage Value

\begin{tabular}{|c|c|}
\hline $\begin{array}{c}\text { Interval } \\
\text { Koefisien }\end{array}$ & Level of Criteria \\
\hline $0 \%-20 \%$ & Poor \\
\hline $21 \%-40 \%$ & Less \\
\hline $41 \%-60 \%$ & Fair \\
\hline $61 \%-80 \%$ & Good \\
\hline $81 \%-100 \%$ & Very good \\
\hline
\end{tabular}

(Riduwan, 2012)

In

conducting the

process of data analysis the author using quantitative approach, for quantitative data derived from the results of questionnaire answers, the authors use scores with the following attitudinal scales:
a. Alternative answer a (strongly agree) score $=5$
b. Alternative answers $b$ (agree) score $\quad=4$
c. Alternative answers c (neutral) score $\quad=3$
d. Alternative answer d (disagree) score $\quad=2$
e. Alternative answer e (strongly disagree) score $=1$

\section{Hypothesis Test}

Hypothesis test is used to test hypothesis wich has formulated by using t-test. In this study, the researcher used Paired Sample T-Tes of software SPSS 21 to know the significancy result of control class and experimental class. The formula is:

$$
t=\frac{\bar{x}_{1}-\bar{x}_{2}}{\sqrt{\frac{\sigma_{1}^{2}}{n_{1}}-\frac{\sigma_{2}^{2}}{n_{2}}}}
$$

Information:

$\mathrm{t}=\mathrm{t}$-test

$\bar{x}_{1}=$ The average score of students in experimental class

$\bar{x}_{2}=$ The average score of students in control class

$n_{1}=$ Number of students in experimental class

$n_{2}=$ Number of students in control class

$\sigma_{1}^{2}=$ Variants of students in experimental class

$\sigma_{2}{ }^{2}=$ Variants of students in experimental class 
Moreover, to measure the significancy test between control class and experimental class, the researcher used ANCOVA test of SPSS 21 Software. The purpose of ANCOVA is to know and see the effect of treatment on variables response by controlling other variables that are quantitative. The formula is:

yij $=\mu+\tau i+\beta x i j+\varepsilon i j, i=1,2, \ldots a$

$\mathrm{j} \quad=1,2, . \mathrm{ni}$

Information:

yij: the response variable value at the $\mathrm{j}$-th junction of observation

xij: the covariate value of the observations corresponding to yij

$\tau i$ : the effect of the $i$ th treatment

$\beta$ : linear regression coefficient

\section{FINDINGS AND DISCUSSION}

\section{Students' Motivation in Control Class}

In control class, there were 36 students of X MIPA 8. The researcher used the learning material based on textbook in X MIPA 8 class. This class has two meetings which discussed two topics namely recount text and advertisement. Hence, the treatment was due to analyze students' motivation in control class using textbook. However, the data analysis has taken by distributing questionnaire in order to measure students' motivation from the use of textbook. Exactly, the questionnaire answered by students of X MIPA 8 class.

The questionnaire was distributed before and after the process of treatment. Each of questionnaire has 25 statements that have to be answered by the students. It has the purpose to measure students' motivation in reading comprehension through the textbook as the learning source. It is also involved two variables of motivation based on the theory of Williams and Burden's framework of L2 motivation (1997) cited from Dornyei (2011), namely internal and external factors of motivation. Internal factor divided into some aspects, they are interest, value, sense of agency, mastery, self - concept, attitudes, emotional. While, external factor divided into some aspects, namely significant others, social interaction, and learning environment

Then, students' motivation in control class indicated each aspect has different percentages and criteria. In several aspects, there was no enhancement from pre-test to post-test percentages that measured in control class. It means, there were several aspects which had same percentages in pre-test and post-test. Precisely, some aspects of students' motivation that have a consistent result of questionnaire before and after treatment, namely interest aspect, sense of agency aspect, self - concept aspect, and emotional aspect. Then, some aspects of students' motivation that have 
increased from the pre - test to post - test are mastery aspect, significant other aspect, and learning environment aspect even though the improving are not really high. Although the result of each aspect for pre - test to post - test are not always improve, all of the aspect result of the questionnaire are categorized as good criteria because the number of the average for each aspects are more than $60 \%$. So, it can be defined that the students' motivation using textbook - based learning in the control class was good.

\section{Students' Motivation in Experiment Class}

Student's motivation in X MIPA 7 as the experimental class is measured by using authentic materials as the learning sources. The researcher implemented the authentic materials from newspaper, diary, wattpad, youtube video, brochure, and other internet sources. The topics of material taught are same with the control class, namely recount text and advertisement. The questionnaire was distributed before and after the process of treatment. Each of questionnaire has 25 statements that have to be answered by the students. It has the purpose to measure students' motivation in reading comprehension through the authentic materials as the learning source.

In line with control class, the questionnaire is also involved two variables of motivation based on the theory of Williams and Burden's framework of L2 motivation (1997) cited from Dornyei (2011), namely internal and external factors of motivation. Internal factor divided into some aspects, they are interest, value, sense of agency, mastery, self - concept, attitudes, emotional. While, external factor divided into some aspects, namely significant others, social interaction, and learning environment.

Furthermore, students' motivation in experiment class indicated that each aspect has different percentages but constantly improved. Every aspects of students' motivation have increased well from the pre - test to the post - test. Precisely, the aspects were interest aspect, value aspect, sense of agency aspect, mastery aspect, self - concept aspect, attitudes aspect, emotional aspect, significant others aspect, social interaction aspect, and learning environment aspect. Moreover, although the result of each aspect from pre - test to post - test are different, all of the aspect result of the questionnaire are categorized as very good criteria because the number of the average for each aspects are more than $80 \%$. So, it can be defined that the students' motivation using authentic materials - based learning in the experimental class was very good.

\section{The Significant Effect of Students' Motivation Between Control and Experiment Class}

Students' motivation in X MIPA7 as experiment class and students' motivation in X MIPA 8 as control class was described above related to the aspects of students' motivation itself. 
Certainly, The average of students' motivation in pre - test of contrrol class has $69.76 \%$ that indicate as the good criteria. But, in the post - test of control class, the average of students' motivation was decreased into $68.87 \%$. It is about $1 \%$ quarrel from the pre - test. However, the post - test result of control class is also categorized as the good criteria.

Moreover, the average of students' motivation in pre - test of experimental class was $69.18 \%$ that indicate as the good criteria. Then, it was increased significantly in the post - test of experimental class that has $86.42 \%$ of average. It means that the result of students' motivation for reading comprehension in experimental class was increased about $17 \%$ after the treatment using authentic materials.

Thus, the significant effect between control class that used textbook-based lerning and experimental class that used authentic materials for reading comprehension was $17 \%$. Explicitly, the significant result between students' motivation in control class and experimental class could be seen in the following chart:

\section{Chart 4.1}

\section{The Students' Motivation Between Control Class and Experimental Class}

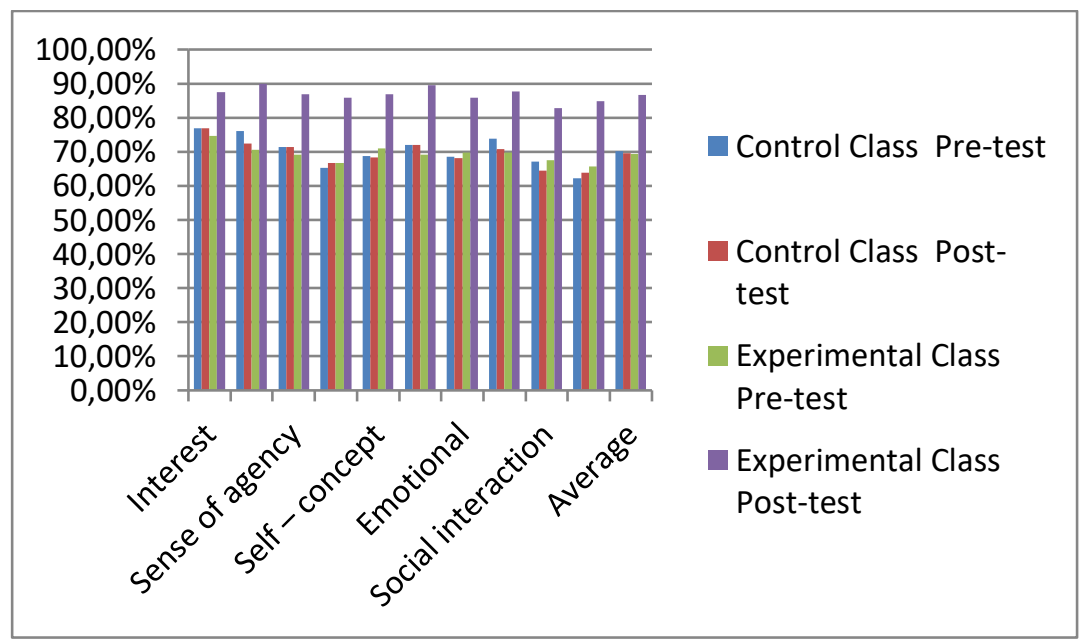

Regarding to the chart above, it is illustrated that all of students' motivation aspects acquired score more that $60 \%$. It means, the classes was good to accepted English learning both by using textbook or authentic materials. However, the result of experimental class was better than the result of control class because the percentages for the aspects in experimental class was higher than the percentage for the aspects in control class. Therefore, it can be defined temporarily that students' motivation for the use of authentic materials for reading comprehension in experimental class was very good. 


\section{Hypothesis Test}

The hypotheses test is used to reveal whether there was any significant difference on students' who used authentic materials in learning and those who were not. Ancova Test was employed by using SPSS 21 Software to test the hypothesis. The data are obtained by using Analysis of Co variances since the scores of both pre-test and post-test were different between experimental and control class. The hypothesis testing between experimental and control class divided into two, i.e. null hypothesis $\left(\mathrm{H}_{0}\right)$ is "There is no significant effect of students" motivation from the use of authentic materials for reading comprehension", while alternative hypothesis $\left(\mathrm{H}_{\mathrm{a}}\right)$ is “There is a significant effect of students' motivation from the use of authentic materials for reading comprehension." Theoretically, the hypothesis could be accepted if the significant level was lower than 0.05 and vice versa. The following table presents the result of hypothesis test:

\section{Table 1 Hypothesis Test of Control Class and Experimental Class ANCOVA Test}

Dependent Variable: Post-test

\begin{tabular}{l|l|l|l|l|l}
\hline Source & $\begin{array}{l}\text { Type III Sum } \\
\text { of Squares }\end{array}$ & Df & $\begin{array}{l}\text { Mean } \\
\text { Square }\end{array}$ & F & Sig. \\
\hline Corrected & $5926.345^{\mathrm{a}}$ & 2 & 2963.172 & 91.280 & .000 \\
Model & 3118.835 & 1 & 3118.835 & 96.075 & .000 \\
Intercept & 378.789 & 1 & 378.789 & 11.669 & .001 \\
Pre-test & 5645.618 & 1 & 5645.618 & 173.912 & .000 \\
Class & 2239.913 & 69 & 32.463 & & \\
Error & 442229.760 & 72 & & & \\
Total & 8166.258 & 71 & & & \\
Corrected & & & & & \\
Total & & & & & \\
\hline
\end{tabular}

In addition, Paired Sample T-Test was employed by using SPSS 21 Software to analyze whether there is a significant effect on students' motivation of using authentic materials for reading comprehension after the treatment in experimental and control class. The hypothesis testing was divided into two, i.e. null hypothesis $\left(\mathrm{H}_{0}\right)$ is “there is no significant effect of students' motivation from the use of authentic materials for reading comprehension", while alternative 
hypothesis $\left(\mathrm{H}_{\mathrm{a}}\right)$ is "there is a significant effect of students' motivation from the use of authentic materials for reading comprehension". Theoretically, the hypothesis could be accepted if the significant level was lower than 0.05 .

Table 2 Hypothesis Test of Pre-Test and Post-Test

\begin{tabular}{c|l|l|l|l}
\hline $\begin{array}{c}\mathbf{N} \\
\text { o. }\end{array}$ & Variable & $\mathbf{T}$ & $\begin{array}{l}\text { Sig. } \\
\text { tailed })\end{array}$ & Interpretation \\
\hline 1. & $\begin{array}{l}\text { Experimenta } \\
\text { 1 Class }\end{array}$ & $\begin{array}{l}11.15 \\
7\end{array}$ & 0.000 & $\mathrm{H}_{\mathrm{a}}$ is accepted \\
\hline 2. & $\begin{array}{l}\text { Control } \\
\text { Class }\end{array}$ & 0.800 & 0.429 & $\mathrm{H}_{\mathrm{a}}$ is rejected \\
\hline
\end{tabular}

\section{Discussion}

In teaching and learning process, there are many things that should be noticed especially in learning English language. One of them is the motivation of students. Generally, English learning subject has 4 skills that need to master by the students, including reading skills. Reading is one of an important and useful skill. In line with the statement of Alwasilah (1993) “......nothing writing without reading". It means that reading is important thing that people should considered because reading is the way to get knowledge, information, pleasure, etc. Moreover, English teachers should make sure that they guide students to get the desire and motivation in reading activity in order to get the great ability in reading also. In case, teacher can use the variation of materials, Medias, methods, and anything that can improve students' learning motivation.

The authentic materials can be used as the learning materials to increase students' motivation. As Gilmore (2007) in Guo (2012) states that authentic materials contain real language produced by a real speakers or writers for a real audience and designed to convey a real message. They relate closely to the learners needs and hence provide a link between the classroom and students' needs in the real world. Regarding to the research which was done in SMA Negeri 1 Sumber, the pre-test and post-test have been administered to both experimental and control class to find out the students' motivation for reading comprehension before and after the treatment.

The data were obtained from the questionnaire of motivation. In pre - test, the statements of questionnaire are about the students' motivation in learning instruction in general, while, the post - test statements of questionnaire are about the students' motivation for reading comprehension 
through the authentic materials in experimental class. While, the post - test of control class is in form of the questionnaire that contain statements about the students' motivation for reading comprehension through the textbook. The treatment stages for both classes are same, what makes different is just the learning materials.

The experimental class was given the treatment by using the authentic materials as the learning materials. Authentic materials are the materials that familiarly found in daily life. This is also supported by Wallace (1992: 145), he defines that authentic texts have been defined as reallife texts, not written for pedagogic purposes, it is written by native speaker and contain "real" language. It always close to the people's life, so that students may easy to find those kind of materials. The kinds of authentic materials are materials from newspaper, magazine, internet, diary book, brochure, youtube video, pamphlet, and so on. In this case, the researcher used the authentic materials from newspaper, brochure, diary, and youtube video. Thus, the topic materials for this research are recount text and advertisement.

In teaching and learning process, the researcher implemented the scientific approach cycle, namely observing, questioning, experimenting, associating and communicating. . Scientific approach is the approach adopted from 2013 curriculum. The 2013 curriculum is a curriculum that can educate future competency, communication skills, ability to think clearly and critically, ability to consider the moral aspects of a problem (Kemdikbud, 2013). In the first meeting, the researcher gave the stimulus to the students relate to the authentic materials, namely from the diary of people and youtube video about experience because the topic material is about recount text. After that, the researcher made a question and answer with the students about the materials. Then, students were devided into some groups. Each of group was given a kind of material from the authentic materials. Thus, students are asked to read the recount text and discussed about the sturucture text of the text and list of the difficult vocabularies that they got.

After that, the researcher gave some questions relate to the text that they got. The questions was given in order to check their understanding about the text. Students were discuss the answer together with their group and presented it to the other students. Moreover, in the second meeting, the materials that given was different topic, namely advertisement. The cycle of learning was same, but the learning materials are from the newspaper. In this case, students are asked to understand about what truly advertisement want to convey to the people with considering the structure of advertisement that they have learned. 
Meanwhile, the control class used the textbook as the learning materials with the scientific approach cycles too. The topic materials that was given were same, namely recount text and advertisement that already exist on their textbook. They read discussed about the text entitled "My Idol" together in the group including text structure, difficult vocabularies, and answer the questions that already exist in the book relate to the text. Thus, for the advertisement topic materials. Students read and discussed about the examples of advertisement in the textbook then identified the information according to the each function of the part of advertisement itself, then presented it to the other students.

Based on the computation of pre-test, the mean score of experimental class was 69.76 and the mean score in control class was 68.87. This result interpreted that the score of experimental class was lower than the control class. The majority of students were still lack in reading enthusiasm. Based on the observation, there are some factors that make students were not really motivated in reading activity, namely they were not really interest to join in reading activity. Some students were like to joking and not really enjoy the reading activity and it made the class were crowded. Then, the learning materials also just taken from the textbook that possibly made they were bored to join the learning. However, the motivation to learn is characterized by long-term, quality involvement in learning and commitment to the process of learning (Ames, 1990). Moreover, their motivation in reading comprehension are good, but it possibly need to be increased.

Whereas, the result of the post-test shows that the mean score of post-test of experimental class was 86.42 and the mean score of control class was 68.87 . Consequently, the mean score of post-test of experimental class was higher than the control class. It means that the better improvement of students' motivation in reading comprehension through authentic materials. This result of mean score was indicated by students being active and responsive in the reading activity. As Richard (2001) said that the teacher used opinion exchange task which learners engage in discussion and exchange of ideas. They were also can comprehend the text well through any assignment that the researcher gave. Moreover, they were motivated to enjoy the learning possibly because the learning materials from authentic materials are more vary and colorful, and they closer with students' life.

The frequency distributed of each aspect of students' motivation in experimental class was improved steadily after the treatment through authentic materials. All of the aspect in experimental class was increased from pre - test to post - test. The mean score of pre - test to post - test in 
experimental class was increased about 16.66\%. Moreover, the Paired Sample T-Test of experimental class showed that the significance level (Sig. (2-tailed)) was 0.00 which less than significance level of 0.05 . Thus, the alternative hypothesis ( $\mathrm{Ha})$ is accepted in which it means that there is a significant effect after the treatment given to the students of experimental class. It is supported by Fadeli (2006) about his study that used authentic materials to improve students' learning interest.

On the other hand, the frequency distributed of each aspect of students' motivation in control class was not always improved in some aspects. The data reveals that there are some aspect of motivation that has increased, consistent and decreased from pre - test to post - test. Thus, the mean score of control class from pre - test to post - test was decreased about $1 \%$. From the explanation above, it can be seen that the result of post - test of students' motivation in control class was decreased.

The researcher assumed that the decline of the post - test result is because the class when treatment held was not really conducive with the timing and class condition. But, according to the mean score of pre - test and post - test in control class, it was categorized as the good critera. In addition, the Paired Sample T-Test of control class showed the significance level (Sig. (2-tailed)) was 0.429 . Its value was higher than the significance level of 0.05 which means the alternative hypothesis (Ha) is rejected. Thus, there is no significant effect after the treatment given to the students of control class. It is also supported by Desitarahmi (2013) reveals that the authentic materials are more effective to improve students' reading comprehension than using textbook.

Furthermore, the Ancova Test Analysis indicate that there is significant effect between those who were taught by using authentic materials and those who were not. The significance level (sig.) of the pre - test and post - test both experimental and control class was 0.00 which was lower than the significance level of 0.05 . Therefore, the alternative hypothesis ( $\mathrm{Ha}$ ) is accepted. It was parallel with the statement of Philips and Shettlesworth 1978; Clarke 1989; Peacock 1997 in Richards (2001) that authentic materials have a positive effect on learner motivation, because they are intrinsically more interesting and motivating than created materials. There is a huge supply of interesting sources for language learning that relate closely to the interest of many language learners. In summary, it can be concluded that there is a significant difference on students' motivation in reading comprehension between students were using authentic materials with students were using the textbook. 


\section{CONCLUSIONS}

This research aimed to find the answer of formulated research question in chapter I, i.e. the students' motivation in reading comprehension both experimental class and control class, and whether there was significance different between them. With regard to the research findings explored in chapter IV, there are three conclusions made.

First, the mean score of the experimental class increased 17.24 point from 69.18 to 86.42 after the implementation of authentic materials. It was also identified by the Paired Sample T-Test which showed the significance level of 0.00 which lower than the significance level of 0.05 and accepting the alternative hypothesis $(\mathrm{Ha})$. Consequently, it means that there is a significant effect after the treatment given to the students of experimental class.

Second, the mean score of the control class decreased about 1 point from 69.76 to 68.87 after they were taught by using textbook. It can be summarize that there is no significant effect after the treatment given to the students. The Paired Sample T-Test also indicated that the significance level was 0.42 which was higher than the significance level of 0.05 .

Third, there is a significant effect on students' motivation for reading comprehension between those who used authentic materials and those who were not. It was indicated by the result of the Ancova Test Analyisis which showed the significance level of both pre-test and post-test was lower than 0.05 , i.e. 0.00 . However, the better improvement is occurred in experimental class since the gain score between pre-test and post-test of the experimental class was higher than the control class, i.e. $0.54>-0$.

Based on the data analysis, there is a positive effect of using authentic materials for reading comprehension on students' motivation. So, the students have responsibility and feel more enjoy in the learning process. It means that authentic materials can be used as one of the alternative materials to enhance students' motivation.

\section{REFERENCES}

AlSalmi, M. 2011. Schemata (Background Knowledge) and Reading Comprehension for EFL Students. Research Journal Specific Education. No. 22

Ames, C.A. (1990). Motivation: What Teachers Need to Know. Teachers College Record 91(3): 409-421.

Anni, Chatarina Tri. 2006. Psikologi Belajar. Semarang: UPT UNNES Press. 
Arikunto, Suharsimi. (2006). Prosedur penelitian: Suatu Pendekatan Praktek (6thed.). Yogyakarta: PT. Rineka Cipta.

Berardo, S.A. 2006. The Use Of Authentic Materials In The Teaching of Reading. The Reading Matrix Vol. 6, No. 2, September 2006.

Brophy, J. (1987). Synthesis of Research on Strategies for Motivating Students to Learn. Educational Leadership

Brown, H. D. (1990). Language assessment principles and classroom practices. San Francisco: State University.

Brown, H. D. (2003). Principle of language teaching and learning. Engel Word Cliffs,NJ: Prentice Hall.

Carrel, P. L, Devine, J., \&Eskey, D. E. (1993). Interactive approach to second language reading. New York: Cambridge University Press.

Davenport, T.R. 2007. Mastering the Critical Reading Test. Wiley, Hoboken, NJ: Canada

Dörnyei, Z and Ushioda E. (2011) Teaching and Researching Motivation. United Kingdom: Pearson Education Limited.

Gilmore, A. (2007). Authentic materials and authenticity in foreign language learning. Language Teaching [online] 40 (2), 97-118.

Grabe, William., Stoller, F. L. (2011). Teaching and Researching Reading. Great Britain: Pearson Education Limited.

Harmer, Jeremy. (2003). The practice of English language teaching. London: Longman.

Harmer, J. 2001. How to Teach English. An Introduction to the Practice of English Language Teaching . England: Longman.

Harmer, J. 2001. The Practice of English Language Teaching 3rd edition. England: Longman.

Lepper, M.R. (1988). Motivational Considerations in the Study of Instruction. Cognition and Instruction 5(4): 289-309.

Mason, Jana M and Kathryn H Au. 1990. Reading Instruction for Today. Harper Collin Publishers USA.

Martinez, A.G. (2002). Authentic materials: An overview. Free resources for teachers and students of English, Karen's Linguistics Issues, 1-7.

Nuttal, C. 1982. 9 Teaching Reading Skills In A Foreign Language. Heineimann Educational Books. London. 
Riduwan. (2008) Belajar Mudah Penelitian Untuk Guru Karyawan dan Peneliti Pemula. Bandung: Alfabeta.

Smith, F. 2004. Understanding reading 6th edition. New Jersey: Lawrence Erlbaum Associate.

Spratt, M., A. Pulverness, and M. Williams. 2005. The TKT (Teaching Knowledge Test) Course. Cambridge: Cambridge University Press.

Sugiyono. 2001. Statistika Untuk Penelitian. Bandung: Alfabeta.

Sugiyono. 2011. Metode Penelitaan Kuantitatif Kualitatif dan R\&D. Bandung: Alfabeta.

Sukirlan, M. 2012. Modul Belajar Mata Kuliah Lesson Planning and Material Development. Bandar Lampung: University of Lampung.

Tadros, L. 2014. Definition and Approaches to Measuring Reading Proficiency. Cello Fact Fact Journal, Vo.2.

Tarigan, H. G. (2008). Membaca sebagai suatu keterampilan berbahasa. Bandung: Angkasa. Permendiknas No. 22 year 2006

The International Journal of Research and Review. Volume 3: 200

Wallace, C.1992. Language Teaching Reading. New York. Oxford University Press.

Widdowson, H.G. (2003). Defining Issues in English Language Teaching. Oxford: Oxford University Press.

Williams, M. and Burden, R.L. (1997) Psychology for Language Teachers. Cambridge: Cambridge University Press.

Wolley, G. 2001. Reading Comprehension: Assisting Children with learning Difficulties. Springer Press. 